Research Article

\title{
Taste Threshold, Salivary Secretion, Blood Pressure and Blood Glucose in Smoking and Non-Smoking Women
}

\author{
Sri Tjahajawati ${ }^{1, a)}$, Anggun Rafisa ${ }^{1, b)}$, Hening Tjaturina Pramesti ${ }^{1, c)}$, Cucu Zubaedah ${ }^{2, d)}$ \\ ${ }^{1}$ Department of Oral Biology, Faculty of Dentistry, Padjadjaran University, Bandung, Indonesia \\ ${ }^{2}$ Department of Community Dentistry, Faculty of Dentistry, Padjadjaran University, Bandung, Indonesia
}

\begin{abstract}
:
Background: WHO reported that $2.7 \%$ of women are active smokers in Indonesia. Smoking can decrease taste sensitivity. The objective of this study was to obtain the taste threshold, salivary secretion, blood pressure and blood glucose in smoking and nonsmoking women.

Materials and Methods: Subjects were 15 smoking women and 38 non-smoking women. The sweet and salt taste threshold was measured by dripping a solution of $\mathrm{NaCl}$ and glucose gradually starting from the lowest to the highest concentration. Blood glucose levels were measured using a glucometer device. Blood pressure was obtained by using a sphygmomanometer. Salivary volume is measured by the spitting method. Salivary $\mathrm{pH}$ value was measured using $\mathrm{pH}$ paper test.

Results: The mean value of sweet taste threshold $(0.04267 \mathrm{M})$, salt taste threshold $(0.03267 \mathrm{M})$, salivary volume $(2.78667 \mathrm{ml})$, blood glucose $(112.83333 \mathrm{mg} / \mathrm{dl})$ and systolic blood pressure $(111.53333 \mathrm{mmHg})$ in smoking women were higher than the mean value of sweet taste threshold $(0.03132 \mathrm{M})$, salt taste threshold $(0.02513 \mathrm{M})$, salivary volume $(2.73026 \mathrm{ml} / 5 \mathrm{~min})$, blood glucose $(107.36842 \mathrm{mg} / \mathrm{dl})$ and systolic blood pressure $(109.89474 \mathrm{mmHg})$ in non-smoking women. In contrast, the mean value of salivary $\mathrm{pH}(6.00)$ and diastolic blood pressure $(73.46667 \mathrm{mmHg})$ in smoking women were lower than the mean value of salivary $\mathrm{pH}(6.25)$ and diastolic blood pressure $(76.18421 \mathrm{mmHg})$ in non-smoking women. There was a significant difference of sweet and salt taste threshold between smoking and non-smoking women $(\mathrm{p}<0.05)$.

Conclusion: Systolic blood pressure was the most contributing variable in explaining the difference between smoking and nonsmoking women, followed by the sweet and salt taste threshold.
\end{abstract}

Keywords: Smoking, taste threshold, salivary secretion, blood pressure, blood glucose.

\section{Introduction}

Tobacco consumption has reached global epidemic proportions. By 2030 there will be about 2 billion smokers in the world. Although this prevalence is not exact, the number of smokers will continue to increase mainly due to the growing population. Approximately 250 million women in the world are smokers. About $22 \%$ of these women are in developed countries and $9 \%$ are in developing countries. The low level of tobacco consumption of women around the world does not reflect the awareness of health, but rather the low social-economic [1]. Indonesia is one of the largest tobacco consumption countries in the world and the third-highest country consuming cigarettes in the world after China and India [2]. The prevalence of the population aged 15 years and over who have a smoking habit is as much as $28.2 \%$ and a part of them are women [3]

Cigarettes contain at least 7000 chemical compound, and most of those chemicals are potentially toxic and carcinogenic substances. These substances have various negative effects on the oral cavity and other body systems [4]. Physiological changes can occur in the oral cavity due to cigarettes such as dry mouth mucosa, decreased saliva flow, susceptible to irritation, dental attrition, and atrophy of mastication [5]. The disadvantages of smoking can indeed strike anyone, but the risk of smoking is more threatening to women. Smoking women risk is 25 percent higher than smoking men. A smoking woman has a double risk of heart disease and lung cancer than smoking men. The disadvantages of smoking in women include: destruction of the skin, affect the reproductive system, disrupt the menstrual cycle including the onset of pain, decrease fertility, increase the risk of breast cancer, uterine, oral cavity, and lung cancer, affect the fetal growth, affect the flow of breast milk, miscarriage, and the death of the fetus [6].

The effects that are often not realized by smokers is a decrease in the ability to taste. Cigarettes smoke and nicotine is part of the cigarette that has the most influencing on the tasting ability. Hot air from cigarette combustion can cause flatting of the tongue papillae, while high levels of nicotine in cigarettes can irritate taste buds, disrupt their nerve impulses to the brain, and affect salivary secretion. Eventually, all of those changes can result in reducing taste sensation [7]. It is proven that the ability to taste can increase again after quitting smoking. The decrease in taste function has a direct effect on salty and sweet taste [7-9]. Sweet taste tasting is the sensation of some organic chemicals such as sugar, while the salt taste is 


\section{Sri Tjahajawati et al / Taste Threshold, Salivary Secretion, Blood Pressure and Blood Glucose in Smoking and Non- Smoking Women}

tasting of salt. Both of taste sensation is accepted by the taste bud in the oral cavity. Normal adult human tongues have 3.000 to 10.000 taste bud and they regenerate continuously. While ages over 45 years, taste buds will degenerate causing a less sensitive taste sensation [10].

Sweet and salt taste can be obtained from a variety of food. Sweet flavors commonly found in foods derived from sucrose (sugar) and salt taste are commonly found in salt [11]. Sugar and salt can create an appetite and serves nutrition for the body's needs as well. Sugar intake in one day is not more than 50 grams, while salt intake in Asian countries is about 9 grams-12 grams or twice higher than the recommendation of the World Health Organization (WHO)[12]. Consumption of sugar and salt may be influenced by the tasting function. Cigarettes smoke may influence tasting function on sweet and salt taste or increasing the threshold of sweet and salt taste. The next domino effect, it can cause uncontrollable of the consumption of sugar and salt or affecting appetite [13]. Then, the changes in appetite will affect nutritional intake. Lastly, someone especially women who lack nutritional intake will experience malnutrition and be vulnerable to diseases [14]. A decrease in the sensitivity of tasting sweet and salty naturally will not threaten survival rapidly but can have a big effect on the quality of life [15].

Based on the above description, it is important to study the effects of smoking on taste threshold, salivary secretion, blood pressure value, blood glucose levels in smoking women. In our preliminary study, it has been showed that there is a difference in the threshold value of sweet and salt taste in a group of elderly and young adults. The result showed that the sweet and salt taste threshold values in the elderly group are higher than in the young adult group. Another study which was conducted on the group of filtered 'kretek' cigarette smokers found that the sweet taste threshold is higher than the non-smoker group.

In this research, we studied the effect of smoking on women, especially on the perception of taste threshold by measuring salivary secretion in terms of volume and $\mathrm{pH}$, blood pressure value and blood glucose levels. Those parameters were chosen assuming that they could be a factor supporting the decrease of taste sensitivity. Saliva plays a role in regulating the sensitivity of taste. In the early stages of the initiation process, saliva will dissolve the food substance so that this substance along with the salivary flow will enter the tasting receptor region.

\section{Study Design:}

A descriptive study with a cross-sectional approach.

\section{Study Population:}

This study population was smoking and non-smoking women who lived nearby Padjadjaran University. The study sample was taken consecutively adjusting to the provisions of the sample size. The number of samples that met the population criteria consisted of 15 smoking and 38 non-smoking women aged 19-35 years.

\section{Study Setting:}

Integrated Laboratory of Faculty of Dentistry, Padjadjaran Univesity.

\section{Study Period:}

April to October 2017

Inclusion Criteria:

The criteria for smoking women samples were having a smoking habit at least 2 years and willing to be a respondent.

\section{Exclusion Criteria:}

Respondents have no local abnormalities and oral diseases affecting the ability to taste, have no systemic disease and diabetes or hypertension

\section{Methodology:}

The primary data was obtained from the measurement of the sweet and salt taste threshold, salivary secretion (volume and $\mathrm{pH})$, blood pressure and glucose level. The threshold value of the sweet and salt taste of samples was measured using a various concentration of sucrose and sodium chloride. The saliva was collected in the tube using a spitting method to measure the volume. The $\mathrm{pH}$ value of saliva was obtained using $\mathrm{pH}$ paper test. Blood samples were taken to measure glucose levels using a glucometer device. Lastly, blood pressure was measured using a digital sphygmomanometer.

\section{Results and Discussion}

Figure 1 shows that the mean value of the sweet and salt taste threshold in smoking women was higher than non-smoking women. The mean value of the sweet taste threshold in smoking women was 0.04267 (SD 0.008209) and nonsmoking women were 0.03132 (SD 0.013238). The mean value of salt taste threshold in smoking women was 0.03267 (SD 0.008837) and non-smoking women were 0.02513 (SD $0.012108)$. Some previous studies also found higher thresholds for the detection of sweet and salt taste in smokers [16,17]. The higher mean value of sweet and salt taste threshold means that smoking women had a lower sensation to sweet and salt taste. A study conducted by Pavlos et al (2009) has confirmed that there were morphological differences in taste buds and vascularization in fungiform papillae in smokers [18]. The cigarette's smoke contacts directly with the tip of the tongue where the sweet taste buds are located. Hot smoke in cigarettes can cause the papillae of the tongue to become flat. High levels of nicotine in cigarettes irritate taste buds and disrupt nerve impulses to the brain, and affect salivary secretions that can lead to reduced tongue sensation to taste [7].

\section{- Smoking Women}

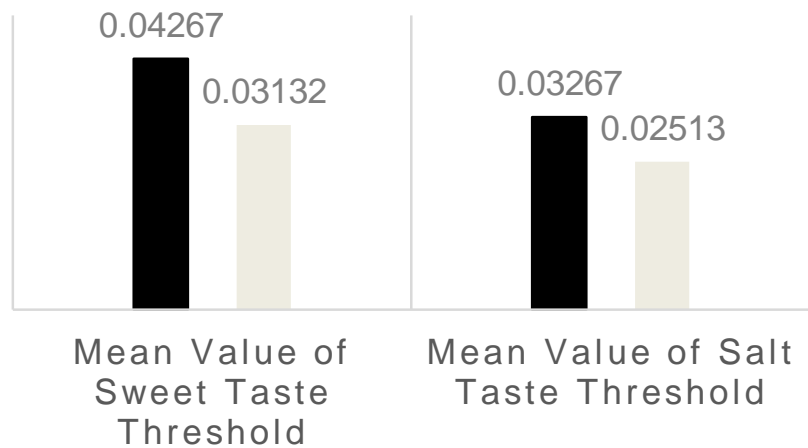

Figure 1. Mean value of taste threshold in smoking and non-smoking women 


\section{Sri Tjahajawati et al / Taste Threshold, Salivary Secretion, Blood Pressure and Blood Glucose in Smoking and Non- Smoking Women}

Figure 2 shows that the mean value of salivary volume in smoking women was 2.78667 (SD 1.327) and just a little bit higher but not statistically significant than non-smoking women 2.73026 (SD 1.216971). On the contrary, the mean value of salivary $\mathrm{pH}$ in smoking women (6.25) was lower than non-smoking women (6.0). Petrušić et al (2015) also found that there were no significant differences in salivary volume between smokers and non-smokers. However, the salivary volume decreases significantly with the duration of smoking and increasing age of smokers [19].

\section{- Smoking Women Non-smoking Women}

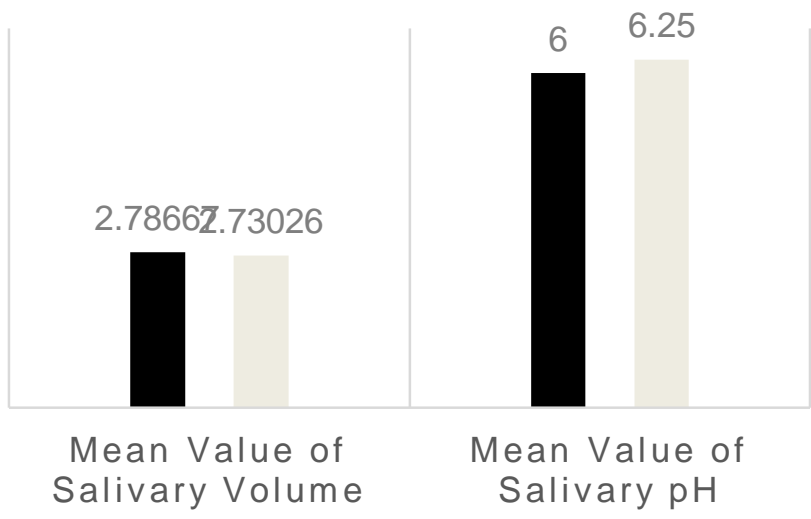

Figure 2. Mean value of salivary secretion in smoking and on-smoking women

The decrease in salivary $\mathrm{pH}$ may affect the health of the oral cavity. Saliva has a buffer ability to regulate the degree of acidity in the oral cavity using components such as proteins, bicarbonate, and phosphates as salivary $\mathrm{pH}$ regulators [20]. Bicarbonate, phosphate, and protein in saliva also have an antibacterial function. Acids produced by bacteria inside the oral cavity can be neutralized by these components by diffusing into the plaque [20,21]. The salivary $\mathrm{pH}$ and buffer's ability also affect the occurrence of caries in the oral cavity [21]. Saliva with a low $\mathrm{pH}$ in between 4.5-5.5 will facilitate the growth of acidogenic bacteria such as Streptococcus mutans and Lactobacillus [22]. Saliva also has a function of lubrication and protection of tooth tissue through the remineralization of enamel with calcium and phosphate $[21,23]$. The decrease in salivary $\mathrm{pH}$ in the oral cavity will cause the rapid demineralization of the tooth element [24]. Changes in salivary $\mathrm{pH}$ also affect the growth of microflora in the periodontal tissue [21,25]. The study by Baliga et al found that the decrease of salivary $\mathrm{pH}$ was associated with the formation of periodontal pockets. Patients with chronic generalized periodontitis have a lower salivary $\mathrm{pH}$ than healthy people [26]. Women are especially susceptible to periodontal disease at various times of their lives. Hormonal changes such as puberty, menstruation, pregnancy, and menopause can cause an exaggerated response to irritants from bacterial plaque. During these times, women experience hormonal changes that can make gums sensitive and increase risks for gum disease [27].
The mean value of blood glucose level in smoking women (112.83, SD 24.68) was higher than non-smoking women (107.37, SD 17.70) as shown in Figure. 3. Systolic blood pressure in smoking women (111.53, SD 10.95) was also higher than non-smoking women (109.89, SD 12.49). In contrast, diastolic blood pressure in smoking women (73.47, SD 9.12) was lower than non-smoking women (76.18, SD 8.74). Smoking allegedly can elevate cortisol level, a stress hormone that usually secreted when the body senses some danger [28]. Elevated cortisol over the long term consistently produces glucose, leading to increased blood sugar levels [29]. It is widely believed that dietary salt leads to increased blood pressure and a higher risk of heart attack or stroke. Salt intake is related to the development of hypertension and in particular the rise in blood pressure with age. The estimated diastolic blood pressure negatively related to salt intake. The estimated effect of salt on blood pressure depends on the statistical adjustments: reduction of salt amounting to $100 \mathrm{mmol}$ per day is estimated to lead to a reduction in systolic pressure in the range from 1 to $6 \mathrm{~mm} \mathrm{Hg}$; for diastolic pressure, the estimated reduction ranges from .03 to $2.5 \mathrm{~mm} \mathrm{Hg}$ [30]. The traditional concepts focus on the tendency for an increase in extracellular fluid volume. Increasing evidence suggests that small increases in plasma sodium may play an important role [31]. A woman who smokes during pregnancy can affect the health of the fetus. The birth weight and blood pressure of a child whose mother smokes during pregnancy differed significantly than whose mother does not. Intra-uterine exposure to maternal cigarette smoking increased children's blood pressure from age one through to age six. This differential relationship persisted after adjustment for the child's current weight and socioeconomic status [32].

In this study, we used Wilks' Lambda for testing the Equality of Group Means as shown in Table 1. There was a significant difference between a mean value of sweet and salt taste threshold in smoking and non-smoking women $(\mathrm{p}<0.05)$, where the mean value of sweet and salt taste threshold in smoking women was higher than non-smoking women. The difference between the other variables in smoking and nonsmoking women in this study was not significant $(p>0.05)$. Table 2 shows that there was a significant difference between smoking and non-smoking women with Wilks' Lambda value $=0.733$ and $p=0.04$.

Table 1. Tests of equality of group means

\begin{tabular}{llllll}
\hline Variable & $\begin{array}{l}\text { Wilks' } \\
\text { Lambda }\end{array}$ & F & df1 df2 & Sig. \\
\hline Sweet Taste Threshold & .843 & 9.514 & 1 & 51 & .003 \\
Salt Taste Threshold & .914 & 4.778 & 1 & 51 & .033 \\
Salivary Volume & 1.000 & .022 & 1 & 51 & .883 \\
Salivary pH & .942 & 3.152 & 1 & 51 & .082 \\
Blood Glucose Level & .984 & .814 & 1 & 51 & .371 \\
Systolic Blood Pressure & .996 & .198 & 1 & 51 & .658 \\
Diastolic Blood Pressure & .980 & 1.015 & 1 & 51 & .318 \\
\hline
\end{tabular}

Standardized Canonical Discriminant Function Coefficients value in Table 3 shows that systolic blood pressure (0.672) 
was relatively more important and the most contributing variable on explaining the difference in smoking and nonsmoking women (0.691), followed by sweet taste threshold, salt taste threshold (0.244) and salivary volume (0.11).

Table 2. The Wilks' Lambda

\begin{tabular}{lclcl}
\hline $\begin{array}{l}\text { Test } \\
\text { Function(s) }\end{array}$ & $\begin{array}{c}\text { ofWilks' } \\
\text { Lambda }\end{array}$ & Chi-square df & Sig. \\
\hline 1 & .733 & 14.728 & 7 & .040 \\
\hline
\end{tabular}

Table 3. Standardized canonical discriminant function Cefficients

\begin{tabular}{ll}
\hline Variable & Function \\
\cline { 2 - 2 } & $\mathbf{1}$ \\
\hline Sweet Taste Threshold & .672 \\
Salt Taste Threshold & .244 \\
Salivary Volume & .011 \\
Salivary pH & -.489 \\
Blood Glucose Level & -.082 \\
Systolic Blood Pressure & .691 \\
\hline
\end{tabular}

\section{Conclusion}

In conclusion, there was a significant difference between the sweet and salt taste threshold between smoking and nonsmoking women. The systolic blood pressure was relatively more important and the most contributing variable in explaining the difference in smoking and non-smoking women, followed by sweet, salt taste threshold and salivary volume.

\section{References}

1. J. Mackay and M. Eriksen, The Tobacco Atlas, WHO, Geneva (2002).

2. Kemenkes RI, Infodatin, Pusat Data dan Informasi Kementerian Kesehatan RI, Jakarta (2015).

3. Kemenkes RI, Riset Kesehatan Dasar 2013, Badan Penelitian dan Pengembangan Kesehatan RI, Jakarta (2013), p. $132-138$

4. R. M. Benjamin, How Tobacco Smoke Causes Disease, U.S Departement of Health and Human Services, U.S.A (2010), p. 2-7.

5. S. Hasibuan, Majalah Kedokteran Gigi USU. 4, 40 (1998).

6. R. R. Huxley and M. Woodward, The Lancet. 378, 1297 (2011).

7. S. Tomassini, V. Cuoghi, E. Catalani, G. Casini and A. Bigiani, Neuroscience. 147, 803 (2007).

8. M. J. Fehrenbach, RDH Magazine. 35, 73 (2015).

9. E.L. Mullings, L. F. Donaldson, J. K. Melichar and M. R. Munafò, J. Psychopharmacol. 24, 1709 (2010).

10.A. C. Guyton and J. E. Hall, Textbook of Medical Physiology 10th edition, Elsevier Saunders, Philadelphia (2010), p. 830-834.

11.R. N. Wasito, Hubungan Antara Fungsi Pengecapan Rasa Asin dengan Status Tekanan Darah pada Lansia, Universitas Gajah Mada, Yogyakarta (2014), p. 134.
12.D. P. Bolhuis, L. P. Newman, and R. S. J. Keast, Chem Senses. 41, 189 (2016).

13.P. Chau, AYM. Leung, H.L.H. Li, M. Sea, R. Chan and J. Woo, PLoS ONE. 10, 1 (2015).

14.J. Sunariani, Yuliati, and B. Alfah, Media Majalah Ilmu Faal Indonesia 6, 182 (2007).

15.S. Kamen and L. B, in Contemporary Geriatric Medicine, Edited S. R. Gambert, Springer, Boston (1986).

16.J. Suliburska, G. Duda, and D. Pupek-Musialik, Przegl Lek. 61,1174 (2004).

17.F. Chéruel, M. Jarlier, and H. Sancho-Garnier, Tob Induc Dis. 15, 15 (2017).

18.P. Pavlos, N. Vasilios, A. Antonia, K. Dimitrios, K. Georgios, and A. Georgios, BMC Ear, Nose and Throat Disorders. 9, 9 (2009).

19. N. Petrušić, M. Posavac, I. Sabol, and M. Mravak-Stipetić, Acta Stomatol Croat. 49, 309 (2015).

20.H. D. Hall, Protective and Maintainance Functions of Human Saliva, University of Oklahoma, Dept. of Periodontics, Oklahoma (1993).

21.P. D. V. Almeida, A. M. T Gregio, M. A. N. Machado, A. A. S. Lima, and L. R. Azevedo, J. Contemp Dent Pract. 9, 072 (2008).

22.D. Soesilo, R. E. Santoso, and I. Diyatri, Dent J: Majalah Kedokteran Gigi 38, 25 (2005).

23. M. Rodian, M. H. Satari and H. E Rolleta, Dent J: Dentika 16, 44 (2011).

24. Minasari, Dent J: Majalah Kedokteran Gigi 4, 33 (1999). 25.E. A. M Kidd and S. J. Bechal, Dasar-Dasar Karies: Penyakit dan Penanggulangannya, EGC, Jakarta (1992).

26.S. Baliga, S. Muglikar and R. Kale, J. Indian Soc Periodontol. 17, 461 (2013).

27.J. Primm, Women and Periodontal Disease, The Advance Institute of Oral Health, Brentwood (2017).

28. A. Steptoe and M. Ussher, Int. J. Psychophysiol. 59, 228 (2006).

29.C. DeVirgilio, Editor, Surgery: A Case Based Clinical Review, Springer, Boston (2015).

30.D. A. Freedman, and D. B. Petiti, Eval Rev. 25, 267 (2001).

31.F. J. He and G. A. MacGregor, Pflugers Arch. 467, 577 (2015).

32. K. V. Blake, L. C. Gurrin, S. F. Evans, L. J. Beilin, I. L. Landau, F. J. Stanley and J. P. Newnham, Early Hum Dev. 57, 137 (2000). 